\title{
From Civil Religion to Presidential Public Theology-A Re-evaluation of the American Civil Religion Phenomenon. The Case of George H. W. Bush
}

\author{
Kjell O. Lejon
}

\begin{abstract}
Since the inauguration of the civil religion debate in the United States in 1967, it has been argued that the religious dimension of American presidency should be understood as a kind of civil religion, normally based upon the definition of Jean Jacque Rousseau, or variations of this his definition. However, in this article the author argues, based upon the empirical material presented in Public Papers of the President and elsewhere, that a more accurate description of the religion dimension of some modern presidencies is public theology. $\mathrm{He}$ uses the presidency of George H. W. Bush as a case study.
\end{abstract}

Keywords: Civil religion, Public Theology, American presidents, Robert N. Bellah, George H. W. Bush

\section{Introduction}

\section{The Civil Religion Debate}

Sociologist Robert N. Bellah's 1967 article "Civil Religion in America" in Daedalus, The Journal of the American Academy of Arts, inaugurated the contemporary American civil religion debate. ${ }^{1}$ The article established Bellah "as a major interpreter of American religion in the second half of the twentieth century," according to the Encyclopedia of Religion and Society. ${ }^{2}$ Since its publication, popular and scholarly attention have been paid to this article's subject of the civil religion phenomenon, which he defines as the "transcendent universal religion of the nation" 3 and the religious dimension of a nation's "beliefs, symbols, and rituals."

Bellah argues that there actually exists alongside of and rather clearly differentiated from the churches an elaborate and well-institutionalized civil religion in America. ${ }^{5}$ He used President John F. Kennedy's Inaugural Address of January 20, 1961 as an example and introduction to the complex subject of civil religion, "or perhaps better, this religious dimension" of American political life. ${ }^{6}$ There are certain common elements of religious orientation that the great majority of Americans share, Bellah claimed, and they play "a crucial role in the development of American institutions and still provide a religious dimension for the whole fabric of American life, including the political sphere."7

Bellah used the phrase "civil religion" to describe this religious dimension and argued both here and also later in The Broken Covenant (1975) that this civil religion "interprets its historical experience in the light of transcendental reality." $\mathrm{He}$ claimed that the inauguration of a president is an important event because "it reaffirms, among other things, the religious legitimation of the highest political authority" in the United States. ${ }^{9}$ Also, Bellah underlines that there is "a consensus that it is a useful way of talking about things that indubitably are out there." 10

\footnotetext{
2 Swatos 1998

3 Swatos 1998

${ }^{4}$ Bellah 1967: 4

5 Bellah1967: 1

${ }^{6}$ Bellah1967: 12

${ }^{7}$ Bellah1967: 3-4

${ }^{8}$ Bellah 1986: 3. See also Angrosino 2002: 263

${ }^{9}$ Bellah 1986: 4. See also Fowler, Hertzke, \& Laura R. Olson 2004: 301

10 Marty 1976: 185
}

${ }^{1}$ According to Bellah, it was Talcott Parsons (Bellah's mentor) who had originally been asked to write the article for Daedalus. Encyclopedia of religion and society 1998. Retrieved Sept. 21, 2011, from http://hirr.hartsem.edu/ency/civilrel.htm. 
Undoubtedly, the term civil religion has been debated since the appearance of Bellah's article in Daedalus, and others have used other terms, for example, a "democratic faith" (a secular form presented for example by Gunnar Myrdal), "religious nationalism" (Charles Henderson) or "religion in general" (Martin Marty). ${ }^{1}$ Historian Sidney Mead describes it as a "religion of the republic" and "national religion," and argues that there are two forms of faith in the United States: a) the faith of specific groups and denominations, and b) an "American faith," i.e. civil religion. ${ }^{2}$ Other terms used are: "civic," "public" and "societal religion;" civic "faith," and even "American Shinto."3

William H. Swatos, Jr. argues that Bellah's early approach "resonates well with the functional sociology of Emile Durkheim and Bellah's mentor, Talcott Parsons." ${ }^{4}$ Crucial is the claim that "civil religion definitionally is an 'objective social fact'." Perry C. Cotham comments on the role of the president in his Politics, Americanism, and Christianity (1976): "Despite the official separation of church and state in our nation, candidates for the highest executive office are competing for a religious office." 6 The President has also been characterized as "the high priest" or "the chaplain" of the nation's civil religion. ${ }^{7}$ Robert S. Alley argues that the strengths of the personalities of the presidents as well as the mood of the nation and the international balance have an essential impact on the message. ${ }^{8}$ Definitely, different aspects of the civil religious heritage are stressed by the presidents. And as I argue, the expressions of civil religion during the presidency of George H. W. Bush (and other modern presidents), stress content of the puritan heritage in a way that it is more correctly to describe the phenomenon as a public theology; certainly if we compare it with Bellah's basic definition used in his 1967 article which is one that reflects the definition presented by Jean-Jacques Rousseau in Du Contrat Social ou Principes Du Droit Politique (Livre Quatrieme, Chapitre huitième: "De la religion civile."). ${ }^{9}$ Rousseau wrote:

There is therefore a pure civil profession of faith of which the Sovereign [the political ruler] should fix the articles, not exactly as religious dogmas, but as social sentiment without which a man cannot be a good citizen or faithful subject... The dogmas of civil religion ought to be few, simple, and exactly worded, without explanation or comment. The existence of a mighty, intelligent, and beneficent Divinity, possessed or foresight and providence; the life to come, the happiness of the just, the punishment of the wicked; the sanctity of the social contract and the laws: these are the positive dogmas. ${ }^{10}$

Thus, he argues that the dogmas of a civil religion are expressed in the beliefs in

a) the existence of God,

b) the survival of the soul after death/the life to come,

c) the reward of virtue/the happiness of the just and punishment of

vice/punishment for the wicked. In this context, he also stressed

d) the exclusion of religious intolerance or the tolerance of diversity

when it comes to private religious opinions.

Religion, in this form-and not in organized traditional forms-was seen as a key element in the social order of a society. In contradiction to Plato's civic religion, based upon strict state control and explicit dogma, Rousseau stressed voluntary agreement and the sovereignty of the will of the people. For both, though, the purpose was to free the polis or society from

\footnotetext{
${ }^{1}$ Angrosino 2002: 245; Swatos 2011; Pierard 2010: 482

2 Fowler, Hertzke and Olson 2004, 302; Swatos 2011: 481

3 Pierard 2010: 480-83

4 Swatos 2011

5 Swatos 2011

${ }^{6}$ Cotham 1976: 127

7 Dunn 1984: 158. Journalist James Reston, New York Times, writes that "the White House is the pulpit of the nation and the president is its chaplain." Cited in the Congressional Record (Oct. 5, 1970), S17106.

${ }^{8}$ Alley 1972: 18. This is true, but Alley exaggerates when he says that these factors "tend to construct a new civil religion in every generation." More correct is to say that what is basically changing is the emphasis on different aspects of the civil religious heritage.

${ }^{9}$ Rousseau 1762

10 Pierard 2010: 484-485
} 
factions and create the possibility of developing a positive character in this polis or society. ${ }^{1}$ Thus, the main purpose of civil religion is to work as a unifying force in a society.

This thought, and its repercussions, has further been discussed with reference to America. Charles W. Dunn writes that in "an effort not to be offensive, presidents usually identify with mainline churches and use inoffensive language of 'civil religion' that attracts, but does not alienate, a cross-section of the religious among the electorate. ${ }^{2}$ Ronald $\mathrm{C}$. Wimberley and William H. Swatos, Jr., states, in the Encyclopedia of Religion and Society (1998), that available social scientific research finds that civil religious beliefs in America "are widely shared and provide a basis for pluralistic social integration across the society." ${ }^{3}$ Also, in The Oxford Handbook on Church and State of 2010, Richard V. Pierard emphasizes this, stating that civil religion contributes to "national integration" and "functions as social glue."4

It is interesting to note that Pierard argues, no doubt with some right, that civil religion has "grown from evangelical consensus to Protestantism-in-general, to Christianity-in-general, to Judeo-Christian tradition-in-general, and finally to deism-in-general." ${ }^{5}$ But, at the same time, I can very clearly describe something of a break in the historical line or development presented by Pierard, since the forms of civil religion used by presidents Ronald Reagan, Bush Sr. and other modern presidents have characteristics that go beyond a deism-in-general type of civil religion. Examples of this phenomenon will be given in the following case study of George H.W. Bush.

\section{George H. W. Bush ${ }^{6}$}

Bush Sr. surprised many by making the following statement at the beginning of his inaugural address on January 20, 1989:

And my first act as President is a prayer. I ask you to bow your heads.

Heavenly Father, we bow our heads and thank You for Your love. Accept our thanks for the peace that yields this day and the shared faith that makes its continuance likely. Make us strong to do Your work, willing to heed and hear Your will, and write on our hearts these words: "Use power to help people". For we are given power not to advance our own purposes, nor to make a great show in the world, nor a name. There is but one just use of power, and it is to serve people. Help us remember, Lord. Amen. ${ }^{7}$

Bush Sr. also stated: "Our challenges are great, but our will is greater. And if our flaws are endless, God's love is truly boundless."8 Thus, already during the first political ceremony of his presidency, a theological message was sent. Bush declared that there is a God, a Heavenly Father, who is worthy of thanks for His boundless love, who has a purpose and will, who listens to prayers and interacts with human lives and the life of the nation, and who blesses the nation. In addition, when the word "Lord" is used in contexts like these, at least a Christian listener most likely connects the words to Jesus Christ.

Prayer was a major theme for Bush Sr. One of the best examples of this is his speech at the Annual National Prayer Breakfast on February 2, 1989. Of course, some interpreters might say that his emphasis on prayer at such an occasion was simply an attempt to win stronger support from the Christian groups represented at the breakfast. But other interpreters might say that this was an opportunity for Bush to talk to people that really understood his personal belief in and reliance on prayer. Bush's statement could have been part of any sermon ever delivered in the Evangelical tradition.

There is no greater peace than that which comes from prayer and no greater fellowship than to join in prayer with others. And coming to the prayer breakfast is, for us, at least, like coming home. The Lord works in mysterious ways. There is nothing

\footnotetext{
${ }^{1}$ Angrosino 2002: 244-245

2 Dunn 1984: 169

3 Swatos 2011

4 Pierard 2010: 480. See, for example, also Wilsey 2015: 20

5 Pierard 2010: 488

${ }^{6}$ For the religious dimensions of the politics of George H. W. Bush, see Lejon 2014.

7 Inaugural Address (Jan. 20, 1989). Weekly Compilation of Presidential Documents (WCPD), 1989, 100. By including a prayer, he

followed the example of Eisenhower on his inauguration on Jan. 20, 1953.

8 WCPD 1989: 101. Inaugural Address (Jan. 20, 1989)
} 
mysterious, however, about His priorities ... Let us thank the Lord for having granted us this day, making it possible for us to spend this time together ... we're facing some serious opportunities and some great opportunities in our country-tough problems and great opportunities. And I believe that a wonderful resource in dealing with them is prayer-not just prayer for what we want but prayer for what is in the heart of God for us individually and as a nation. And shouldn't we also remember, with all that we have to be grateful for, to pause each day to offer a prayer of thanksgiving. All of us should not attempt to fulfil the responsibilities we now have without prayer and strong faith in God. Abraham Lincoln said: 'I've been driven many times to my knees by the overwhelming conviction that I have nowhere else to go.' Surely he was not the first President, certainly not the last, to realize that ... I can also tell you from my heart that I freely acknowledge my need to hear and to heed the voice of Almighty God. I began my Inaugural Address with a prayer out of deep sense of need and desire of God's wisdom in the decisions we face. And if we're to walk together toward a more caring, more generous America, let us all share in paving with a prayer. ${ }^{1}$

In Proclamation 6104 National Day of Prayer, in 1990, Bush first asked his fellow Americans to join him in prayer for our children and then continued, "Let us strive to help each of them sink their roots into the rich soil of God's love for the beings He has made in His own image. Let us show them through prayer that we, too, like our Nation's Founders, seek our shelter-our rock and our salvation in the Arms of God."2

Throughout his presidency, Bush referred to God. It can be noted that the expression "God bless" occurs an astounding 916 times in Bush's official remarks and addresses etc., during his presidency. ${ }^{3}$ Bush describes God as someone who listens to and answers prayers, ${ }^{4}$ who is the primary reason for the existence of human beings, ${ }^{5}$ the Creator that has given man unalienable rights, who has a plan, ${ }^{6}$ a will and has given man his free will. ${ }^{7}$ God is Almighty, ${ }^{8}$ Providence, ${ }^{9}$ and a heavenly Father before whom you should be humble,,$^{10}$ a just Father of all. ${ }^{11}$ God is someone to whom you turn for help and guidance, ${ }^{12}$ who you should obey, ${ }^{13}$ someone to whom you should give praise and thanks, ${ }^{14}$ who calls people to do things, ${ }^{15}$ who loves and whose love is

\footnotetext{
1 WCPD 1989: 141-142. Remarks at the Annual National Prayer Breakfast (Feb. 2, 1989)

2 WCPD 1989: 371. Proclamation 6104-National Day of Prayer (March 6, 1990)

${ }^{3}$ See: http://www.presidency.ucsb.edu/ws/index.php\#axzz1MUr2AOa9, search Keywords: God bless. Records found: 916

4 WCPD 1990: 370. Proclamation 6104-National Day of Prayer (March 6, 1990), "The Bible tells us what we have often seen for ourselves: that God answers the prayers of those who place their trust in Him."

5 WCPD 1990: 140. Remarks at the Annual Convention of the National Religious Broadcasters (Jan. 29, 1990), "While God can live without man, man cannot live without God."; WCPD 1989: 1683. Remarks at the Bicentennial Convocation at Phillips Academy in Andover, Massachusetts (Nov. 5, 1989), "without God's help we can do nothing."; WCPD 1991: 197. Proclamation 6253-Nation Doctors Day (Feb. 21, 1991), "the Almighty has reserved for Himself the power to create life."; WCPD 1989: 1250. Proclamation 6012-National Pledge of Allegiance Day (Aug. 15, 1989), "We believe in God; we believe that all men are created equal."

6 WCPD 1989: 1708. Remarks at the Welcoming Ceremony for President Corazon C. Aquino of the Philippines (Nov. 9, 1989), "President Aquino has often spoken of her belief that God has a plan. And I don't doubt it."

7 WCPD 1990: 1411. Proclamation 6181-Religious Freedom Week (Sept. 20, 1990), "His will...recognizing Man's free will as both the design and gift of the Creator."

8 WCPD 1989: 733. Remarks Signing the Martin Luther King Jr. Federal Holiday Commission Extension Act (May 17, 1989), "The Almighty God..."

9 WCPD 1989: 643. Remarks at the Bicentennial Celebration of George Washington's Inauguration in New York City (April 30, 1989), "He turned to God ... surely depend on Providence."

10 WCPD 1989: 102. Proclamation 5936-National Day of Prayer and Thanksgiving (Jan. 20, 1989). "I am humble before God ... let us all Americans kneel humbly before our Heavenly Father."

11 WCPD 1990: 954. Proclamation 6147-Father's Day (June 14, 1990), "...the one who is the just and loving Father of us all."

12 WCPD 1991: 97; Remarks at the 50th Anniversary Observance of Franklin D. Roosevelt's Four Freedom Speech (Jan. 30, 1991),

"So we ask God to bless us, to guide us, and to help us through whatever dark nights we still may face; WCPD 1989; 102. Proclamation 5936 (Jan. 20, 1989), "... seek His counsel ..."

13 WCPD 1991: 505; 102. Proclamation 6280-National Day of Prayer (April 25, 1991): "... obey His Commandments."

14 WCPD 1989: 1767. Proclamation 6073-Thanksgiving Day (Nov. 17, 1989), "Praise to God for His goodness and generosity...we also remember that one gives praise to God not only through prayers of Thanksgiving, but also through obedience to His Commandments and service to others, especially those less fortunate than ourselves."

15WCPD 1990: 416 Message on the Observance of St. Patrick's Day (March 13, 1990), "God was calling him to take part in yet another extraordinary adventure."
} 
boundless. ${ }^{1}$ God is a God before whom you live, ${ }^{2}$ who cares about His people. ${ }^{3}$ In his arms you can seek shelter. ${ }^{4}$ He is our rock and our salvation, ${ }^{5}$ a merciful Father, ${ }^{6}$ who will, finally, call us home. ${ }^{7}$

In summary, Bush's picture of God is portrayed in pieces, like pieces in a mosaic. All of these pieces seem to reflect the traditional Christian understanding of the God of the Bible in America. It can be noted that, many passages are directly quoted from the Scriptures. It almost seems as if Bush is teaching Americans about God and who God is. It is likely that there is a connection to something in his background. As he said: "I did teach Sunday school."

When it comes to Jesus, Bush declared that "at Christmas, we, too, rejoice in the mystery of God's love for us-love revealed through the gift of Christ's birth." Jesus is called our Savior, who came to live among ordinary men. The incarnation was of "miraculous nature;" the birth of Christ "changed the course of history" and brought "light of hope to a world dwelling in the darkness of sin and death." Two thousand years later, Bush reflected, "the shining promise of that first Christmas continues to give our lives a sense of peace and purpose." If we are guided by the example of Christ's life, our deeds and words can help others share in "the joy of man's Redemption," he said. Kind and selfless deeds performed for others can "rekindle in our hearts and in our communities the light of that first Christmas." We should "recall what our Savior's life means to the world," rededicate ourselves to sharing the love that gives greater meaning and joy to Christmas and to every moment of life."

One year later, in preparation for the celebration of Christmas in 1990, Bush brought up an old prophesy from the book of Isaiah. He mentioned the fulfillment of prophesy, again called Jesus "our Savior" and used the description "the Christ Child," noting that the incarnation radically altered human history, and mentioned the teachings of Jesus.

Christ's brief time on Earth was devoted to tending the physical and spiritual needs of His flock: healing the sick, feeding the hungry, and illuminating the path to eternal salvation. His Incarnation radically altered the course of human history by challenging men and women to live according to the will of our just and merciful Father in Heaven ... let us be mindful of the true meaning of His life on earth and especially of His greatest commandment: to love God with all our heart and to love our neighbor as ourself ... let us strive, by following Christ's example in word and deed, to make peace on Earth a reality for all of God's children. ${ }^{10}$

Concerning the Bible, Bush Sr. that it contains the "revelations of God's intervention in human history, the Bible offers moving testimony to His love for mankind." He cited Abraham Lincoln, who called the Bible "the best gift God has given to man," and Woodrow Wilson, who said, "The Bible is the word of life ... When you have read the Bible you will know that it is the Word of God, because you will have found it the key to your own heart, your own happiness, your own duty." Furthermore, Bush declared that the Bible's value is timeless and that its significance transcends the boundaries between nations and languages since it holds a universal message. He finally invited all "Americans to discover the great inspiration and knowledge that can be obtained

\footnotetext{
1 WCPD 1990: 371. Proclamation 6104-National Day of Prayer (March 6, 1990). "...guarded by the love of God"; WCPD $1989: 101$. Inaugural Address (Jan. 20, 1989), "God's love is truly boundless"; WCPD 1989: 1072. Message to the National Assembly in Warsaw, Poland (July 10, 1989), "God, in His infinite wisdom and love."

2 WCPD 1989: 643. Remarks at the Bicentennial Celebration of George Washington's Inauguration in New York City (April 30, 1989), "Before ... the eyes of God."

3 WCPD 1990: 370. Proclamation 6104-National Day of Prayer (March 6, 1990), "our Creator looks for His children, longing for them to come to Him and to do His will."

4 WCPD 1990: 371. Proclamation 6104-National Day of Prayer (March 6, 1990)

5 WCPD 1990: 371. Proclamation 6104-National Day of Prayer (March 6, 1990). "... seek our shelter ... in the arms of God."

${ }^{6}$ Message on the Observance of Christmas (Dec. 18, 1990), retrieved Aug. 25, 2017, from

http://www.presidency.ucsb.edu/ws/index.php?pid=19165\&st=christmas\&st1=http://www.presidency.ucsb.edu/ws/index.php?pid=19 165\&st=\&st1=\#axzz1MUr2AOa9

7 WCPD 1989: 603. Remarks at the Memorial Service for Crewmembers of the U.S.S. lowa in Norfolk, Virginia (April 24, 1989), "We will not—cannot, as long as we live—-know why God has called them home."

8 WCPD 1989: 1341. Remarks to the National Baptist Convention in New Orleans, Louisiana (Sept. 8, 1989)

9 WCPD 1989: 1968-1969. Message on the Observance of Christmas (Dec.18, 1989)

10 Message on the Observance of Christmas (Dec. 18, 1990). Retrieved May 17, 2011, from

http://www.presidency.ucsb.edu/ws/index.php?pid=19165\&st=\&st1=\#axzz1MUr2AOa9
} 
through thoughtful reading of the Bible."1 The teachings of the Scriptures are eternal. ${ }^{2}$ The official material yields plenty of evidence of direct or indirect quotations from the Bible. ${ }^{3}$ They are used in a variety of circumstances and for a variety of purposes.

Bush Sr. viewed religion as foundational to American freedom and for this reason he called on people to always "remember that we are one nation under God and that we honor Him with the lives we lead."4 Bush blended American history and faith by asserting that Americans have "a heritage of bravery, of faith in God, of liberty and human dignity, and the Golden Rule: 'Do unto others as you would have them do unto you."'5 The three pillars of society were seen as faith in God, faith in country, and faith in one another. ${ }^{6}$ The United States is stated to be "one nation under God" and Bush underlined that "without God's help we can do nothing. With God's help there is nothing we cannot do, for our children and for the world."7

In summary, an examination of the presidential material during Bush Sr.'s presidency clearly provides extensive material that underlines not only a general civil religion or a deism-in-general, but a theistic approach to God, a classical Christian understanding of Jesus, a traditional Evangelical understanding of the Bible and an interpretation that connects an active God with the United States. The United States is portrayed as a nation under God.

\section{Conclusion}

For the reasons presented above, I argue that there is relevance in defining the religious views of Bush Sr. as a public theology or maybe presidential public theology rather than a civil religion. This conclusion is based upon the president's official pronouncements and his adherence to and reliance upon a transcendental or religious reality with a vocabulary and content steeped deeply in the traditional American-Evangelical form of Christianity and partly, but to a lesser extent, to the Enlightenment heritage, which have permeated the American experience throughout the nation's history. Similar theological themes are apparent, for example, when examining statements made by Bush Sr:s predecessor, president Ronald Reagan. ${ }^{8}$

The phenomenon be best described as a public theology since it is public and not private or in any sense classified. Also, it is public since it addresses all; it is concerned with the individual citizen and it is perceived as having relevance for all citizens as well as for the wellbeing of the society as a whole. Both the presidential messages and "the message of the nation" can be characterized as theology since they deal with a transcendental dimension which clarifies that the nation is a nation "under God," that the motto of the nation is "In God We Trust," and that we relate to God as an active God in foundational national documents, and that we describe God, God's work, His incarnation in Jesus Christ etc., and other religious (mostly outspokenly traditional Christian] aspects in various ways through presidential addresses remarks and proclamations etc. Theology literally means "knowledge about God," and that theology is manifested in frequent messages on God, describing who God is, what God does etc. It can also be viewed as theology in a broader sense, since theology can be used as a foundational base, not least ethically, in ordering civil society and morally guiding the nation as well as the individuals of the society. It is a religious dimension that is intended to be the purpose and vision of the nation and its individuals-including, and not least the President of the United States.

Thus, the public theology exhibited during the Bush Sr. presidency is different from the classical civil religion definition used by Robert N. Bellah, rooted in Jean-Jacques Rousseau in Du Contrat Social ou Principes Du Droit Politique, aligned with

\footnotetext{
1 WCPD 1990: 293-294. Proclamation 6100-International Year of Bible Reading (February 22, 1990)

2 WCPD 1991: 87. Remarks at the Annual Convention of the National Religious Broadcasters (Jan. 28, 1991)

3 See, for example, WCPD 1989: 1768. Proclamation 6073-Thanksgiving Day (Nov. 1989); WCPD 1991: 88. Remarks at the Annual Convention of the National Religious Broadcasters (Jan. 28, 1991); WCPD 1989: 1178. Remarks at the Annual Meeting of the National League of POW/MIA Families and on Signing the National POW/MIA Recognition Day Proclamation (July 28, 1989); WCPD 1990: 760. Remarks at the Liberty University Commencement Ceremony in Lynchburg, Virginia (May 12, 1990); WCPD 1990: 551. Message on the Observance of Passover (April 9, 1990); WCPD 1990: 1902. Remarks to the United States Army Troops Near Dhahran, Saudi Arabia (Nov. 22, 1990); WCPD 1990: 373. Remarks to Members of the American Society of Associations Executives (March 6, 1990). See Lejon 2014: 123-124

${ }^{4}$ WCPD 1989: 616. Remarks to Members of the Hispanic-American Community in Los Angeles, California (April 25, 1989)

${ }^{5}$ WCPD 1989: 935. Remarks at the Cheltenham High School Commencement Ceremony in Wyncote, Pennsylvania (June 19, 1989)

${ }^{6}$ WCPD 1989: 1388. Remarks at the South Dakota Centennial Celebration in Sioux Falls (Sept. 18, 1989)

7 WCPD 1989: 1683. Remarks at the Bicentennial Convention at Phillips Academy in Andover, Massachusetts (Nov. 5, 1989)

${ }^{8}$ Lejon 1988
} 
conventional Enlightenment thought. Neither is it correctly defined as a "religions nationalism" (as "state Shinto" in Japan), nor a non-theistic simple "democratic faith" a la Myrdal, John Dewey or J. Paul William. ${ }^{1}$ The civil religion that Bellah describes is rooted heavily in secular rational thought based on the Enlightenment's reliance on reason, empiricism, and the scientific method. In contrast, the presidential public theology advocated by President $\mathrm{H}$. W. Bush (and other modern presidents) is grounded in the Bible and a Christian faith based on revelation and the American Christian religious tradition. In many ways, the tension between these two competing intellectual traditions has shaped American public and private life. $^{2}$

Therefore, even though the presidential era of Bush Sr. includes some elements of what has traditionally been labelled civil religion, I argue that it is more meaningful to characterize his pronouncements as public theology or presidential public theology, since these terms more accurately define the religious foundations and dimensions of their presidencies.

In further research, an in-depth comparison between the religio-political rhetoric of Bush Sr. and his successors' is of interest, as well as Bush's use of history, i.e. how historical places, artefacts, events and persons are used in Bush's official presidential material, and thereby adequately reveal Bush's underlining both of the importance of a historical consciousness among Americans and the need of a cultural memory in order to accentuate a national identity. By this, light can also be shed on Bush's saluted interpretation of the U.S. history.

\section{References}

[1] Alley, R. S. (1972). So help me God. Religion and the presidency. Richmond, VA: John Knox Press.

[2] Angrosino, M. (2002). Civil Religion Redux. In Anthropological Quarterly 75, no. 2 (Spring 2002): 239-267.

[3] Bellah, R. N. (1967). Civil Religion in America. Daedalus 96 (Winter 1967): 1-21. Retrieved Sept. 21, 2011, from http://www.robertbellah.com/articles_5.htm.

[4] Bellah, R. N. (1986). Habits of the Heart. Individualism and commitment in American life. New York: Perennial Library, Harper \& Row Publishers.

[5] Cotham, P. C. (1976). Politics, americanism, and Christianity. Grand Rapids, Ml: A Conon Press Book.

[6] Davis, D. H. (Ed.) (2010). The Oxford handbook of church and state in the United States. Oxford/New York: Oxford University Press.

[7] Dunn, C. W. (1984). American political strategy. Historical perspective and theoretical analysis. New York: Praeger Publishers.

[8] Encyclopedia of religion and society. (1998). Retrieved Sept. 21, 2011, from http://hirr.hartsem.edu/ency/civilrel.htm.

[9] Fowler, R. B., Hertzke, A. D., \& Olson R. (2004). Religion and politics in America. Faith, culture and strategic choices ( $3^{\text {rd }}$ ed.). Boulder/Oxford, Great Britain: Westview Press.

[10] Lejon, K. O. U. (1988). Reagan, religion and politics. The revitalization of "a nation under god" during the 80s. Lund: Lund University Press.

[11] Lejon, K. O. (2014). George H. W. Bush. Faith, presidency, and public theology. Frankfurt am Main/Oxford/New York: Peter Lang.

[12] Marty, M. E. (1976). A nation of behavers. Chicago: University of Chicago Press.

[13] Pierard, R. V. (2010). The role of civil religion in American society. The Oxford handbook of church and state in the United State, Davis, D. H. (Ed.) (pp. 479-496). Oxford: Oxford University Press.

\footnotetext{
1 Pierard 2010: 482

2 Singer 1969: 19: "American history is characterized in its political aspects by a continuing conflict between the Puritan political philosophy on the one hand and the rise of the democratic conception of the state and human liberty which has emanated from nonBiblical sources."
} 
[14] Public papers of the president. (1984-1992). Washington D.C.: The Office of the Federal Register, National Archives and Record Service, General Services Administration.

[15] Rousseau, J.-J. (1762). Du contrat social ou principes du droit politique. Retrieved Sept. 21, 2011, from http://classiques.uqac.ca/classiques/Rousseau_jj/contrat_social/Contrat_social.pdf.

[16] Singer, C. G. (1969). A theological interpretation of American history. Nutley, NJ: Craig Press.

[17] Swatos, W. H. Jr. (1998). Encyclopedia of religion and society. Walnut Creek, CA: Altamira Press. Retrieved Sept. 11, 2011, from http://hirr.hartsem.edu/ency/civilrel.htm.

[18] Weekly Compilation of presidential documents. (1984-1992). Washington D.C.: The Office of the Federal Register, National Archives and Record Service, General Services Administration.

[19] Wilsey, John D. (2015). American exceptionalism and civil religion. Reassessing the history of an idea. Downers Grove: IVP Academic. 